\title{
Flax seed allergy in children: an emerging allergen?
}

\author{
Andrew O'Keefe ${ }^{1 *}$, Sandeep Kapur ${ }^{2}$, Gregory Rex², Wade Watson ${ }^{2}$ \\ From Canadian Society of Allergy and Clinical Immunology Annual Scientific Meeting 2010 \\ Victoria, Canada. 3-6 November 2010
}

\section{Background}

Flax is a plant that is widely cultivated and has multiple uses. The seed has been increasingly used in food, and the fibers are used in textiles. Oils have also been extracted from the seed for use as a laxative and in industrial preparations. Allergic reactions to flax seed ingestion as well as linseed oil (flaxseed oil) ingestion have been described in the literature in adults (1-5), but not in children.

\section{Material and methods}

We report four cases of flax seed allergy in children.

\section{Results}

See table 1.

\section{Conclusions}

Few cases of flax seed allergy have been described in the literature. As the use of flax seed in foods becomes more prevalent, this will likely become a more important cause of allergic reactions in the future.
Published: 4 November 2010

\section{References}

1. Alonso L, Navarro JA, Garces M, Carretero P: Anaphylaxis caused by linseed (flaxseed) intake. Journal of Allergy and Clinical Immunology 1996, 98(2):469-470.

2. Black WC: Flax hypersensitiveness. JAMA 1930, 94:1064.

3. Grant LR: A report of six cases of flax seed sensitization with review of the literature. The Journal of Allergy 1931, 3:469-477.

4. Lezaun A, et al: Anaphylaxis from linseed. Allergy 1998, 53:105-106.

5. Leon $F$, Rodriguez M, Cuevas M: The major allergen of linseed. Allergy 2002, 57(10):968.

doi:10.1186/1710-1492-6-S2-P6

Cite this article as: O'Keefe et al.: Flax seed allergy in children: an emerging allergen?. Allergy, Asthma \& Clinical Immunology 2010 6(Suppl 2): P6.

Author details

${ }^{1}$ Department of Pediatrics, Memorial University, St. John's, Newfoundland.

${ }^{2}$ Department of Pediatrics, Dalhousie University, Halifax, Nova Scotia.

\section{Table 1}

\begin{tabular}{|c|c|c|c|c|c|c|}
\hline Case & Age & Gender & $\begin{array}{l}\text { Multiple food } \\
\text { allergies? }\end{array}$ & Food containing flax seed: symptoms & $\begin{array}{l}\text { Skin test to } \\
\text { flax }\end{array}$ & Open challenge \\
\hline 1 & $1 \mathrm{y} 5 \mathrm{~m}$ & $\mathrm{~F}$ & no & granola bar: urticaria, angioedema & $5 \mathrm{~mm}$ & not done \\
\hline 2 & $9 y$ & M & yes & muffin: oral "tingling" & $4 \mathrm{~mm}$ & $\begin{array}{c}\text { oral pruritus, throat } \\
\text { clearing }\end{array}$ \\
\hline 3 & $5 y$ & M & yes & bread: vomiting/urticaria (two episodes) & $7 \mathrm{~mm}$ & not done \\
\hline 4 & $8 y$ & M & yes & $\begin{array}{l}\text { fruit smoothie: angioedema of lips } \\
\text { same fruit smoothie without flax seed before and since: no } \\
\text { symptoms }\end{array}$ & pending & pending \\
\hline
\end{tabular}

\footnotetext{
* Correspondence: a.okeefe@mun.ca

'Department of Pediatrics, Memorial University, St. John's, Newfoundland

Full list of author information is available at the end of the article
} 